\title{
Identifikasi Area Pengembangan RTH sebagai Fungsi Ekologis Penyerap Air Hujan di Kecamatan Rungkut Kota Surabaya
}

\author{
'Tisa Angelia*, 2Eko Budi Santoso \\ ${ }^{1}$ Program Studi Arsitektur, Universitas Merdeka Surabaya, ${ }^{2}$ Program Studi Manajemen Pembangunan Kota, Institut \\ Teknologi Sepuluh Nopember Surabaya \\ *tisaangelia78@gmail.com
}

\begin{tabular}{l}
\hline INFO ARTIKEL \\
\hline Riwayat Artikel: \\
Diterima:1-3-2019 \\
Disetujui: 23-5-2019 \\
\hline
\end{tabular}

\section{Kata Kunci:}

Analisa Overlay Kelurahan Kalirungkut RTH penyerap air hujan GOS Rain Water Absorption Kalirungkut Subdistrict Overlay Analysis

\begin{abstract}
ABSTRAK
Abstrak: Perubahan penggunaan lahan mengakibatkan Ruang Terbuka Hijau (RTH) sebagai bagian dari infrastruktur hijau semakin berkurang. Identifikasi area yang berpotensi dikembangkan RTH sebagai penyerap air hujan bertujuan untuk mengurangi banjir/genangan air di Kecamatan Rungkut. Jenis penelitian yang digunakan adalah penelitian kuantitatif, dengan teknik analisa overlay. Berdasarkan hasil analisa overlay didapatkan beberapa area yang memiliki bobot tertinggi untuk dikembangkan RTH penyerap air hujan, yaitu Perumahan Tulus Harapan (11,7\%) dan Perumahan Rungkut Harapan (11,7\%). Hasil penelitian adalah Kelurahan Kalirungkut sebagai area administrasi terkecil yang akan lebih memudahkan dalam pengambilan kebijakan pemerintah yang berkaitan dengan pengembangan RTH penyerap air hujan
\end{abstract}

\begin{abstract}
Changes in land use have resulted in decreasing green open space as part of green infrastructure. Identification of areas that have potential to develop green open space as rain water absorbers aims to reduce flooding/puddle in Rungkut Distric. The type of research used is quantitative, with overlay analysis techniques. Based on the results of the overlay analysis, there are some areas had the highest weight for developing rainwater absorbent green open space, namely Tulus Harapan Housing (11,7\%) and Rungkut Harapan Housing (11,7\%). The results of this research were the Kalirungkut Subdistrict as the smallest administrative area that would facilitate goverment policy making related to the development of rainwater absorbing green open space.
\end{abstract}

\section{A. LATAR BELAKANG}

Ruang terbuka hijau (RTH) merupakan area dengan ekosistem luas yang dapat memerangi penurunan kualitas lingkungan kota dan meningkatkan kesejahteraan hidup penduduk kota (Wolch, Byrne, \& Newell, 2014). Kerusakan ruang terbuka hijau dapat menurunkan kualitas lingkungan, baik kualitas kehidupan maupun kesehatan manusia (Jim, 2004). Undang-undang No.26 Tahun 2007 tentang Penataan Ruang menyebutkan perencanaan tata ruang wilayah kota harus memuat rencana penyediaan dan pemanfaatan ruang terbuka hijau yang luas minimalnya sebesar 30\% dari luas wilayah kota, yaitu 10\% RTH privat dan 20\% RTH publik.

Fungsi RTH sebagai fungsi ekologis memiliki peran sebagai penyerap air hujan. RTH sebagai fungsi penyerap air hujan adalah RTH suatu kawasan yang ditanami pepohonan maupun rerumputan yang dapat memperbaiki struktur tanah sehingga laju resapan air hujan dapat dipertahankan (Budi, Basuki Setyo, 2013). RTH sebagai fungsi ekologis penyerap air hujan berada disekitar waduk yang dapat 
memperkecil atau memperlambat limpasan air permukaan (surface run-off) pada saat hujan turun pembawa air di bawah tanah sangat diperlukan didalam suatu sistem drainase (Pamekas, 2013).

Surabaya Timur semakin berkembang pesat dengan terus bertambahnya pembangunan apartemen atau bangunan tingkat tinggi sebagai dampak dari semakin banyak universitas yang ada di kawasan ini (Himawan, 2016). Perkembangan pembangunan di Surabaya Timur juga menyebabkan perubahan penggunaan lahan dari pertanian maupun permukiman menjadi perdagangan dan jasa disekitar jalan MERR IIC (Murthi dalam Angelia, 2017). Selain itu, perubahan penggunaan lahan dan luasan RTH di Kecamatan Rungkut dari tahun 2011 sampai 2015 menunjukkan bahwa ketersediaan RTH baik RTH aktif dan pasif belum memadai dalam memenuhi fungsi ekologis sebagai penyerap air hujan (Angelia, 2017).

Perubahan guna lahan menyebabkan ketersediaan RTH belum memadai dalam upaya menciptakan lingkungan yang bebas banjir/genangan air di Kecamatan Rungkut. Berdasarkan data Bina Marga dan Pematusan Kota Surabaya (2015) disebutkan bahwa antara tahun 2011 sampai 2013 terdapat penambahan titik genangan, dari 8 titik area genangan menjadi 10 titik. Titik genangan air tersebut berada disekitar luasan 0,15 ha sampai 72 ha, lama genangan air 40 menit sampai 90 menit, dan tinggi genangan air dari $4 \mathrm{~cm}$ sampai $30 \mathrm{~cm}$. Tujuan penelitian ini adalah untuk memberikan informasi berdasarkan data yang ada mengenai area mana saja yang membutuhkan pengembangan RTH sebagai fungsi penyerap air hujan di Kecamatan Rungkut.

\section{B. METODE PENELITIAN}

Pendekatan yang digunakan dalam penelitian ini adalah pendekatan rasionalisme, dimana rasio dalam pendekatan ini dipandang sebagai sumber dari segala kebenaran (Wilardjo, 2011). Pendekatan ini juga memandang bahwa realita dikaitkan dengan teoriteori yang ada dihubungkan dengan data empirik. Jenis penelitian yang digunakan adalah kuantitatif, dimana penilitian kuantitatif berdasarkan data kuantitatif atau angka, dengan banyak responden, menggunakan kuisioner dan memiliki tujuan penelitian mengkonfirmasi. Pada penelitian kuantitatif ini dilakukan penarikan kesimpulan dengan deduktif-induktif, yaitu dimulai dengan teoriteori umum sebagai konsep yang kemudian merumuskan sesuatu atau beberapa hipotesis untuk diuji.

Data yang digunakan dalam penelitian ini adalah data primer berupa observasi dan pengumpulan informasi melalui kuisioner dan angket terhadap stakeholders terkait yang didapatkan dari analisa
(Kodoatie, 2013). Keberadaan RTH sebagai bidang yang mampu meresapkan air kedalam lapisan stakeholder. Analisa stakeholders yang dilakukan berdasarkan TUPOKSI dan keahlian masing-masing stakeholder mendapatkan 11 stakeholders yang akan menjadi responden baik dari instansi, akademisi, masyarakat dan swasta. Data sekunder dilakukan dengan melakukan survey instansi yang berkaitan dengan pemenuhan data penelitian. Metode analisa yang digunakan dalam penelitian ini, dapat dilihat pada gambar 1.

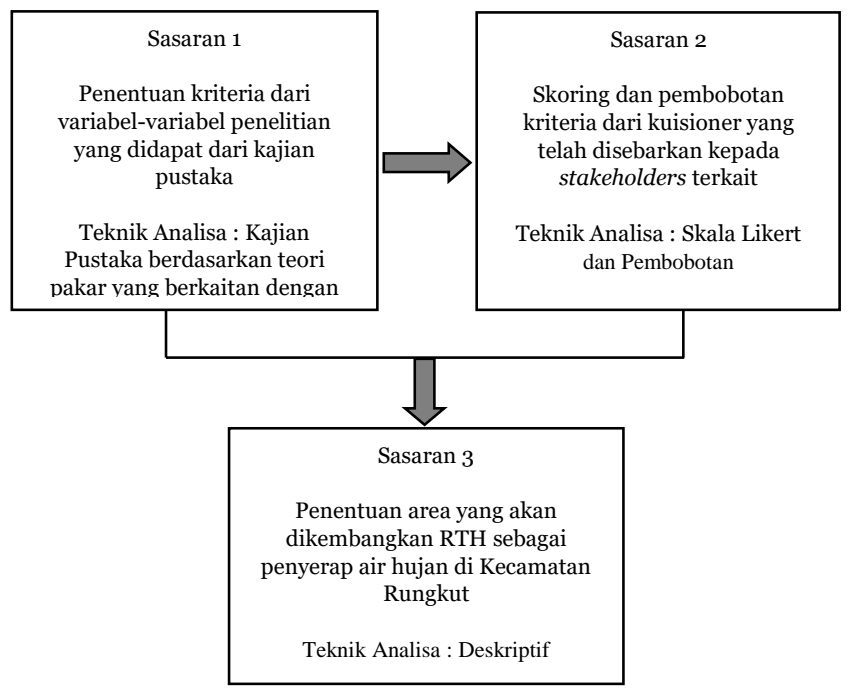

Gambar 1. Metode Analisa

\section{HASIL DAN PEMBAHASAN}

\section{Batas Wilayah Administrasi}

Wilayah studi adalah 5 (lima) kelurahan yang memiliki titik genangan air sebagai akibat belum memadainya RTH sebagai penyerap air hujan di lingkup Kecamatan Rungkut Kota Surabaya. Batas wilayah studi di Kecamatan Rungkut adalah :

Utara : Kecamatan Sukolilo dan Kelurahan Wonorejo Rungkut

Timur : Selat Madura

Selatan : Kecamatan Gunung Anyar

Barat : Kecamatan Tenggilis Mejoyo

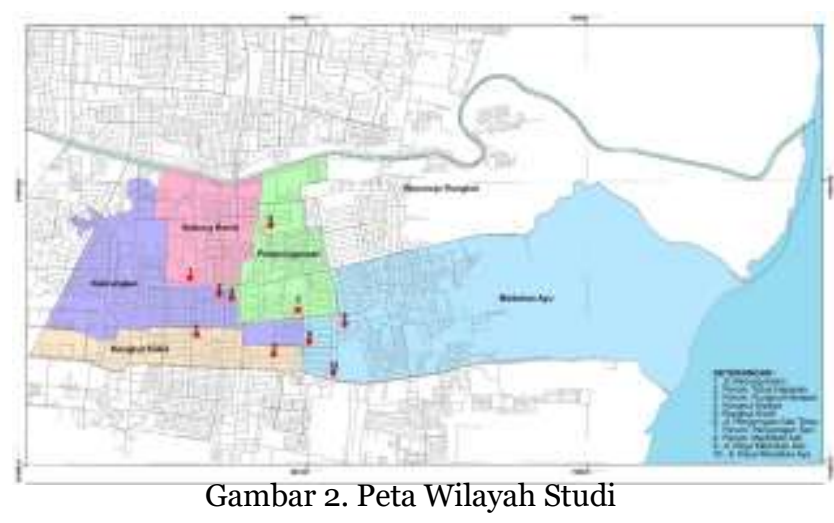

2. Penilaian Kriteria Penentuan Area 
Identifikasi area yang berpotensi dikembangkan RTH sebagai fungsi ekologis penyerap air hujan di Kecamatan Rungkut menggunakan teknik analisa overlay. Teknik analisa overlay diawali dengan adanya skoring dan pembobotan kriteria yang digunakan sebagai penentuan area dalam identifikasi. Kriteria yang didapatkan dari studi literatur ditentukan melalui penyebaran kuisioner terhadap stakeholders terkait yang didapatkan dari analisa stakeholders. Stakeholders yang berpengaruh dalam penelitian ini berjumlah 11 orang, yang antara lain 5 tokoh masyarakat, yaitu lurah dari 5 kelurahan dengan titik genangan di Kecamatan Rungkut.

Faktor-faktor internal yang merupakan variabel penelitian dalam menentukan area didapatkan dari kajian literatur ataupun teori-teori yang berkaitan dengan penelitian ini, seperti teori perubahan guna lahan, teori hidrologi, teori siklus hidrologi, dan teori drainase kota. Teori-teori tersebut dianalisa sehingga menghasilkan variabel-varibel yang mendukung ataupun membatasi dalam analisa penentuan area selanjutnya.

Penyebaran kuisioner terhadap 11 responden dari stakeholders terkait dianalisa menggunakan skala likert untuk mendapatkan kriteria-kriteria yang sesuai dengan penelitian berdasarkan persepsi stakeholders dan kondisi eksisting wilayah studi. Analisa likert yang dilakukan dalam penelitian ini menghasilkan 3 faktor yang memiliki kesimpulan kurang setuju (KS). Kesimpulan yang dihasilkan dari wawancara dan kuisioner lebih diartikan bahwa faktor tersebut kurang dan tidak disetujui untuk menjadi kriteria penelitian, sehingga 3 faktor tersebut yaitu kepadatan penduduk, harga lahan dan kondisi fisik infrastruktur jalan tidak termasuk menjadi kriteria penelitian. Kriteria-kriteria yang selanjutnya akan dibobotkan adalah :

Tabel 1.

Kriteria Penentuan Area

\begin{tabular}{llcc}
\hline No. & $\begin{array}{c}\text { Kriteria-kriteria } \\
\text { penelitian }\end{array}$ & $\begin{array}{c}\text { Index } \\
(\%)\end{array}$ & Kesimpulan \\
\hline 1 & Kepadatan Bangunan & 89 & SS \\
2 & Prosentase Bangunan & 87 & SS \\
3 & Kedalaman Genangan & 85 & SS \\
4 & Luas Genangan & 84 & SS \\
5 & Durasi Genangan & 84 & SS \\
6 & Kapasitas Drainase & 82 & SS \\
& Peresap Air & & \\
7 & Jenis Bangunan & 78 & S \\
8 & Keadaan & 78 & S \\
& Topografi/Kelerengan & & \\
\hline
\end{tabular}

Sumber : Analisa, 2017

Berikut Kondisi setiap kriteria yang menjadi data pendukung untuk analisa overlay dalam penentuan area penelitian :

a. Kondisi Kepadatan Penduduk, Jenis Bangunan, dan Prosentase Bangunan

Penggunaan lahan di Kecamatan Rungkut secara keseluruhan berdasarkan Rencana Pembangunan Jangka Panjang Daerah Kota Surabaya (2005-2025) merupakan unit pengembangan (UP) tersier dalam pengembangan Kota Surabaya. Sebagai UP tersier kecamatan ini menjadi kawasan permukiman, pendidikan, perdagangan dan jasa,
Tisa Angelia, Identifikasi Area Pengembangan

lindung terhadap alam, dan industri. Kondisi sebagai UP tersier membawa pengaruh besar kepada kepadatan dan prosentase bangunan di kawasan ini. Kepadatan bangunan terlihat dari bertambahnya jumlah bangunan dari luas lahan yang ada, sedangkan prosentase bangunan merupakan perbandingan luas seluruh lantai dasar bangunan gedung dengan luas lahan yang dikuasai.

Tabel. 2

Kepadatan dan Prosentase Bangunan Kelurahan dengan Titik Genangan di Kecamatan Rungkut

\begin{tabular}{clcc}
\hline No. & Kelurahan & $\begin{array}{c}\text { Kepadatan } \\
\text { Bangunan } \\
\text { (x jumlah/ha) }\end{array}$ & $\begin{array}{c}\text { Persentase } \\
\text { Bangunan } \\
\text { (\%) }\end{array}$ \\
\hline 1. & Rungkut Kidul & 96 & 89 \\
2. & Medokan Ayu & 73 & 80 \\
3. & Penjaringan & 98 & 83 \\
& Sari & & 93 \\
4. & Kedung Baruk & 121 & 96 \\
5. & Kalirungkut & 103 & \\
\hline
\end{tabular}

Sumber : RDTRK UP Rungkut, 2016

\section{b. Kondisi Kedalaman Genangan, Luas Genangan, dan Durasi Genangan}

Kondisi topografi Kecamatan Rungkut sebagai dataran rendah merupakan komndisi yang mudah menerima aliran air permukaan terutama dari dataran tinggi yang berada di bagian barat Kota Surabaya. Genangan air mudah terjadi di kawasan kecamatan ini sebagai kawasan yang keseluruhan adalah dataran rendah.

Tabel. 3

Luas Kelurahan dengan Titik Genangan di Kecamatan Rungkut

\begin{tabular}{clc}
\hline No. & \multicolumn{1}{c}{ Kelurahan } & $\begin{array}{c}\text { Luas Wilayah } \\
\left(\mathrm{ha}^{2}\right)\end{array}$ \\
\hline 1. & Rungkut Kidul & 163,88 \\
2. & Medokan Ayu & 801,15 \\
3. & Penjaringan Sari & 169,99 \\
4. & Kedung Baruk & 135,06 \\
5. & Kalirungkut & 147,33 \\
\hline \multicolumn{2}{l}{ Sumber $:$ Kantor Kecamatan Rungkut, 2O16 }
\end{tabular}

c. Kondisi Drainase Peresap Air Hujan

Kondisi drainase di Kecamatan Rungkut memiliki kedalaman saluran agak dangkal, mengandung sampah dan sedimen. Selain itu, kapasitas eksisting sudah tidak mampu mengalirkan debit banjir rencana yang bertambah besar seiring dengan berkurangnya resapan karena berubah fungsi guna lahan dari ruang terbuka hijau menjadi lahan terbangun, sehingga masih terdapat banjir/genangan air di kawasan tertentu saat hujan deras.

Elevasi dataran di kecamatan ini relatif rendah terhadap permukaan laut saat pasang. Area kecamatan ini juga rawan terjadi banjir ataupun genangan disaat hujan deras yang bersamaan dengan laut pasang karena letaknya yang berdekatan dengan pantai. Kondisi peresapan air yang tidak terlepas dari bagian ruang terbuka hijau (RTH) perkotaan di Kecamatan Rungkut berada dalam kondisi yang masih belum sempurna sebagai peresap air hujan, baik dari kualitas maupun kuantitasnya. 


\section{d. Kondisi Topografi}

Topografi merupakan kondisi tinggi rendahnya muka bumi, sehingga dapat diketahui ketinggian suatu tempat. Keadaan topografi Kecamatan Rungkut berpengaruh pada penentuan area penelitian karena memiliki ketinggian $4.6 \mathrm{~m}$ dari permukaan air laut dan kemiringan $<3 \%$, sehingga merupakan dataran rendah yang rawan tergenang air disaat air laut pasang ataupun hujan deras.

Kondisi dataran rendah ini memiliki kemampuan untuk membentuk ruang terbuka hijau dengan lebih mudah karena kondisi tanah yang subur. Vegetasi-vegetasi dapat tumbuh dengan tidak terlalu sulit dalam kondisi tanah yang subur., namun tetap memerlukan pengolahan yang baik.

\section{Teknik Pembobotan}

Pembobotan dilakukan karena ada kriteria yang berperan lebih daripada kriteria yang lain. Pembobotan yang dilakukan dalam penelitian ini berdasarkan kuisioner pembobotan yang diperoleh dari pendapat 11 responden ahli dalam teknik skoring penentuan kriteria. Pembobotan dilakukan dengan menggunakan rumus :

$$
\begin{aligned}
& \text { Pembobotan }=\frac{\text { Total Score } \mathrm{x} 100 \%}{\mathrm{~N}} \\
& \mathrm{~N}=\text { Nilai 'Total Score dari semua kriteria }
\end{aligned}
$$

Hasil dari teknik pembobotan yang dilakukan terhadap 11 responden ahli tersebut, adalah sebagai berikut :

Tabel 4.

Hasil Analisa Pembobotan

\begin{tabular}{llcc}
\hline No. & $\begin{array}{c}\text { Kriteria-kriteria } \\
\text { penelitian }\end{array}$ & $\begin{array}{c}\text { Total } \\
\text { Skor } \\
\text { Respon } \\
\text { den }\end{array}$ & $\begin{array}{c}\text { Pembobotan } \\
\text { (\%) }\end{array}$ \\
\hline 1 & Kepadatan Bangunan & 49 & 13.4 \\
2 & Prosentase Bangunan & 48 & 13.1 \\
3 & Kedalaman Genangan & 47 & 12.8 \\
4 & Luas Genangan & 46 & 12.5 \\
5 & Durasi Genangan & 46 & 12.5 \\
6 & Kapasitas Drainase & 45 & 12.3 \\
7 & Peresap Air & 43 & 11.7 \\
8 & Jenis Bangunan & 43 & 11.7 \\
& Keadaan & & \\
\hline Total Nilai : & 367 & 100 \\
\hline
\end{tabular}

Sumber : Hasil Analisa, 2017

Hasil pembobotan menunjukkan bahwa kepadatan bangunan memiliki bobot tertinggi, yang mana kondisi tersebut akan memberikan porsi terkecil terhadap keberadaan RTH sebagai fungsi ekologis penyerap air hujan, selain itu juga disebabkan oleh adanya penggunaan perkerasan untuk memenuhi fungsi aktivitas bangunan itu sendiri seperti lahan parkir, jalan akses menuju bangunan, dll. Hasil pembobotan selanjutnya juga menunjukkan bahwa prosentase bangunan yang mempengaruhi adanya perkerasan di suatu lingkungan bangunan, kondisi genangan yang berkaitan dengan kondisi drainase di suatu kawasan, jenis bangunan dan topografi suatu area dengan melihat beberapa jenis bangunan dalam penggunaan lahan terbangun sebagai bangunan permanen dan perkerasan, serta kondisi topografi yang merupakan dataran rendah akan mempengaruhi terjadinya genangan.

\section{Analisa Penentuan Area}

Overlay adalah teknik analisis dengan metode spasial yang digunakan dalam menentukan area penelitian. Metode ini menangani data dalam evaluasi kesesuaian lahan dengan cara digital yang menggabungkan beberapa peta informasi sesuai kriteria yang ada. Analisa overlay atau super impose dilakukan dengan cara meng-overlay-kan peta-peta kondisi eksisting berdasarkan kriteria yang ada.

Pembobotan pada setiap kriteria di 10 (sepuluh) area titik genangan di Kecamatan Rungkut yang didapat dari data Dinas Bina Marga dan Pematusan Kota Surabaya 2015, dilakukan dengan melakukan skoring yang berdasarkan tabel skoring masing-masing kriteria terlebih dahulu. Hasil analisa skoring akan menunjukkan area titik genangan beserta bobot masing-masing.

Area dengan bobot tertinggi di dalam lingkup batas wilayah studi yaitu Kelurahan Kalirungkut. Penetapan batas administrasi terkecil yaitu kelurahan digunakan karena dapat memahami lokasi sebagai pengembangan RTH, selain juga memudahkan perolehan data, memudahkan penentuan stakeholders serta memudahkan penerapan dari suatu konsep kebijakan pemerintah. Hasil akhir dari analisa adalah adanya beberapa area dengan bobot tertinggi dalam satu kelurahan, sehingga penentuan lokasi penelitian mengambil wilayah dalam satu kelurahan yang memiliki area-area penelitian dengan bobot tertinggi.

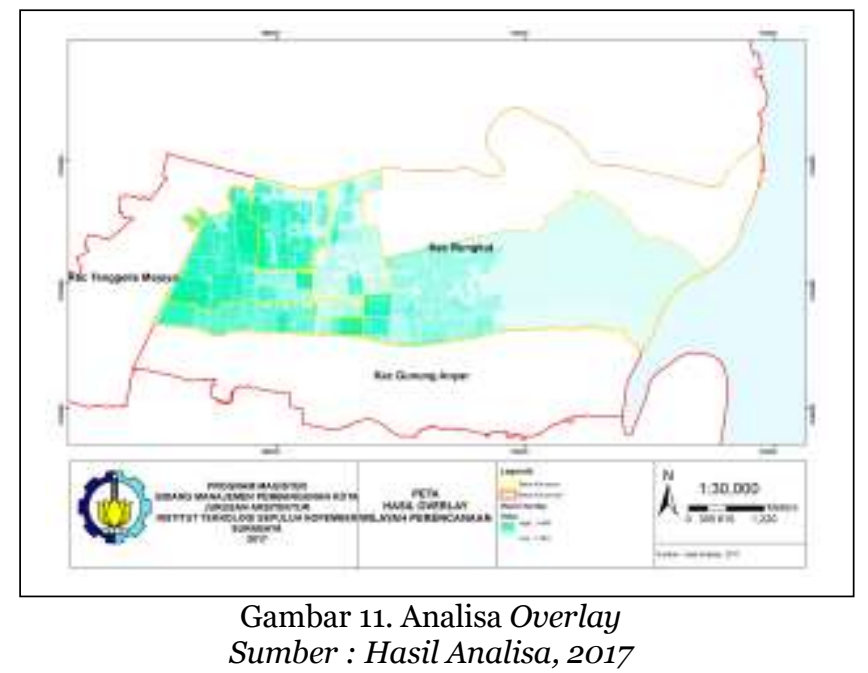

Hasil analisa skoring dalam overlay, menunjukkan beberapa area dengan bobot tertinggi di Kecamatan Rungkut, yaitu Perumahan Tulus Harapan (11,7\%) dan Perumahan Rungkut Harapan (11,7\%) berada dalam satu batas administrasi yaitu Kelurahan Kalirungkut, sedangkan area genangan 
lainnya yang memiliki bobot lebih kecil tersebar di kelurahan-kelurahan lain di Kecamatan Rungkut. Berdasarkan hasil analisa dan kemudahan penelitian dalam unit batas administrasi kelurahan, maka area penelitian yang membutuhkan pengembangan RTH sebagai fungsi ekologis penyerap air hujan adalah Kelurahan Kalirungkut di Kecamatan Rungkut.

Tabel 5 .

Nilai Skoring dan Pembobotan Area-area Genangan Air di Kecamatan Rungkut

\begin{tabular}{|c|c|c|c|}
\hline No & $\begin{array}{c}\text { Area } \\
\text { Genangan }\end{array}$ & $\begin{array}{c}\text { Total } \\
\text { Nilai } \\
\text { Skoring }\end{array}$ & $\begin{array}{c}\text { Pembobotan } \\
\text { Area (\%) }\end{array}$ \\
\hline 1 & $\begin{array}{l}\text { Perumahan } \\
\text { Tulus } \\
\text { Harapan }\end{array}$ & 3.624 & 11.7 \\
\hline 2 & $\begin{array}{l}\text { Perumahan } \\
\text { Rungkut } \\
\text { Harapan }\end{array}$ & 3.624 & 11.7 \\
\hline 3 & $\begin{array}{l}\text { Kedungase } \\
\mathrm{m}\end{array}$ & 3.382 & 10.9 \\
\hline 4 & $\begin{array}{l}\text { Jl.Penjaring } \\
\text { ansari } \\
\text { Timur }\end{array}$ & 3.247 & 10.5 \\
\hline 5 & $\begin{array}{l}\text { Jl.Raya } \\
\text { Medokan } \\
\text { Asri }\end{array}$ & 3.239 & 10.5 \\
\hline 6 & $\begin{array}{l}\text { Rungkut } \\
\text { Kidul }\end{array}$ & 2.866 & 9.3 \\
\hline 7 & $\begin{array}{l}\text { Rungkut } \\
\text { Madya }\end{array}$ & 2.860 & 9.3 \\
\hline 8 & $\begin{array}{l}\text { Perumahan } \\
\text { Penjaringan } \\
\text { sari }\end{array}$ & 2.734 & 8.8 \\
\hline 9 & $\begin{array}{l}\text { Jl.Raya } \\
\text { Medokan } \\
\text { Ayu }\end{array}$ & 2.723 & 8.8 \\
\hline 10 & $\begin{array}{l}\text { Perumahan } \\
\text { Medokan } \\
\text { Asri }\end{array}$ & 2.606 & 8.4 \\
\hline Total & Nilai Bobot & 30.905 & 100.0 \\
\hline
\end{tabular}

\section{SIMPULAN DAN SARAN}

\section{Kesimpulan}

Berdasarkan Analisa likert yang dilakukan dalam penelitian ini dihasilkan 3 faktor kesimpulan kurang setuju (KS). Kesimpulan yang dihasilkan dari wawancara dan kuisioner lebih diartikan bahwa faktor tersebut kurang dan tidak disetujui untuk menjadi kriteria penelitian, sehingga 3 faktor tersebut yaitu kepadatan penduduk, harga lahan dan kondisi fisik infrastruktur jalan tidak termasuk menjadi kriteria penelitian. Hasil Analisa likert juga menunjukkan bahwa 8 faktor lain dapat menjadi kriteria dalam penentuan area penelitian, yaitu kepadatan bangunan, prosentase bangunan, jenis bangunan, kondisi genangan, kondisi drainase dan topografi di Kecamatan Rungkut.

Analisa overlay yang diawali dengan skoring dan pembobotan di 10 titik genangan yang berada di 5 kelurahan Kecamatan Rungkut berdasarkan kriteriakriteria yang sudah didapatkan dari analisa sebelumnya menyimpulkan tentang area-area yang berpotensi untuk dikembangkan RTH sebagai
Tisa Angelia, Identifikasi Area Pengembangan

penyerap air hujan. Perumahan Tulus Harapan dengan bobot area $11,7 \%$ dan Perumahan Rungkut Harapan dengan bobot area 11,7\% berada dalam satu batas administrasi yaitu Kelurahan Kalirungkut. Berdasarkan hasil analisa dan kemudahan penelitian dalam unit batas administrasi kelurahan, maka area penelitian yang membutuhkan pengembangan RTH sebagai fungsi ekologis penyerap air hujan adalah Kelurahan Kalirungkut di Kecamatan Rungkut.

\section{Saran}

Setelah melakukan kegiatan penelitian ini, maka saran yang diberikan untuk penelitian selanjutnya yang berkaitan dengan pemetaan mengenai area pengembangan RTH penyerap air hujan adalah sebagai berikut :

1. Setelah memperoleh peta spasial hendaknya dilakukan pengecekan ke area tersebut dengan mengambil gambar lokasi, sehingga data yang didapatkan lebih akurat.

2. Pada penelitian selanjutnya diharapkan dapat lebih mempersempit atau memperjelas area pengembangan RTH sebagai penyerap air hujan.

3. Hasil dari penelitian ini diharapkan dapat menjadi data pendukung untuk penelitian-penelitian selanjutanya yang berkaitan dengan penanggulangan banjir di Kecamatan Rungkut maupun Kota Surabaya.

\section{DAFTAR RUJUKAN}

[1] Angelia, T. (2017). Konsep Pengembangan Ruang Terbuka Hijau sebagai Fungsi Ekologis Penyerap Air Hujan di Kecamatan Rungkut Kota Surabaya. Institut Teknologi Sepuluh Nopember.

[2] Himawan, A. N. (2016). The Factors Which are Influencing the Development of Apartment in Surabaya ( Based on Consumer and Developer Preference ), 5(06), 685-690.

[3] Jim, C. Y. (2004). Green-space preservation and allocation for sustainable greening of compact cities, 21(4), 311-320.

https://doi.org/10.1016/j.cities.2004.04.004

[4] Wilardjo, S. B. (2011). Aliran-aliran dalam filsafat ilmu berkait dengan ekonomi. Jurnal.Unimus.Ac.Id, 1-19.

[5] Wolch, J. R., Byrne, J., \& Newell, J. P. (2014). Landscape and Urban Planning Urban green space, public health, and environmental justice : Landscape and Urban Planning, 125, 234-244.

https://doi.org/10.1016/j.landurbplan.2014.01.017

[6] Dinas Binamarga \& Pematusan Kota Suarabaya, 2016, Data Genangan Kota Surabaya 2010-2015.

[7] Dinas PU Cipta karya dan Tata Ruang Kota Surabaya, 2016. Data Lahan Terbangun Kota Surabaya 20112014 .

[8] Purnawati, Erna, 2013. Kawasan genangan air Kota Surabaya akan berkurang 30\%. Sumber : 
23 | Jurnal Planoearth | Vol. 4, No. 1, Februari 2019, hal 18-23

http://surabayaraya.blogspot.co.id/2013/04/peta-

kawasan-rawan-banjir-di-surabaya.html Diakses : 25

Oktober 2015. 